University of Nebraska - Lincoln

DigitalCommons@University of Nebraska - Lincoln

$6-2013$

\title{
A Survey of Aquatic Invertebrate Communities in Nebraska Sandhill Lakes Reveals Potential Alternative Ecosystem States
}

Jeffrey C. Jolley

South Dakota State University, jeffrey_jolley@fws.gov

Emily S. Albin

Mark A. Kaemingk

mkaemingk2@unl.edu

David W, Willis

Follow this and additional works at: https://digitalcommons.unl.edu/usfwspubs

Jolley, Jeffrey C.; Albin, Emily S.; Kaemingk, Mark A.; and Willis, David W, "A Survey of Aquatic Invertebrate Communities in Nebraska Sandhill Lakes Reveals Potential Alternative Ecosystem States" (2013). US Fish \& Wildlife Publications. 536.

https://digitalcommons.unl.edu/usfwspubs/536

This Article is brought to you for free and open access by the US Fish \& Wildlife Service at DigitalCommons@University of Nebraska - Lincoln. It has been accepted for inclusion in US Fish \& Wildlife Publications by an authorized administrator of DigitalCommons@University of Nebraska - Lincoln. 


\title{
Surveys
}

\section{A Survey of Aquatic Invertebrate Communities in Nebraska Sandhill Lakes Reveals Potential Alternative Ecosystem States}

\author{
Jeffrey C. Jolley,* Emily S. Albin, Mark A. Kaemingk, David W. Willis
}

\section{J.C. Jolley}

U.S. Fish and Wildlife Service, Columbia River Fisheries Program Office, 1211 SE Cardinal Court, Vancouver, Washington 98683

\author{
E.S. Albin \\ 855 Oak Street Northeast, Hutchinson, Minnesota 55350
}

\section{M.A. Kaemingk, D.W. Willis}

Department of Natural Resource Management, South Dakota State University, SNP 138, Box 2140B, Brookings, South Dakota 57007

\begin{abstract}
Aquatic invertebrate communities are important to shallow lake ecosystem form and function, providing vital components to the food web and thereby important to achieving lake management goals. We characterized lake invertebrate communities and physicochemical variables in six Nebraska Sandhill lakes and examined these characteristics within an alternative stable state framework. Surveys were conducted during 2005 within each of these lakes by sampling aquatic macroinvertebrate abundance, zooplankton abundance and biomass, phytoplankton biomass, and physicochemical variables. When placed within an alternative stable state framework, the response variables exhibited a gradient of different ecosystem states. Two lakes appeared congruent with the clear water state (dense submergent vegetation, high invertebrate abundance and diversity, and low phytoplankton), two lakes were congruent with the turbid water state (high phytoplankton, low vegetation coverage, and low invertebrate abundance and diversity), and two lakes were intermediate, likely in a state of hysteresis (i.e., multiple states under equal environmental conditions). Principal component groupings further supported these findings by following similar lakespecific patterns with attributes of each stable state grouping meaningfully according to the observed lake states. The lakes contained varied fish communities, potentially influencing many measured metrics, through a top-down mechanism. Generally, lakes dominated by piscivorous fish displayed the clear water state, whereas lakes with abundant planktivores displayed the turbid water state. Shallow lakes containing dense invertebrate communities likely provide a rich food base to important fauna (migratory waterfowl) that aid in reaching desired management objectives for these systems. Multiple small lakes, in proximity, displaying divergent ecosystem states invites the opportunity for more in-depth analyses of driving mechanisms that will undoubtedly add to our ability to effectively manage these systems in the future.
\end{abstract}

Keywords: Sandhill lakes; aquatic invertebrate; zooplankton; phytoplankton; alternative stable state; ecosystem; hysteresis

Received: August 18, 2012; Accepted: February 13, 2013; Published Online Early: March 2013; Published: June 2013

Citation: Jolley JC, Albin ES, Kaemingk MA, Willis DW. 2013. A survey of aquatic invertebrate communities in Nebraska Sandhill lakes reveals potential alternative ecosystem states. Journal of Fish and Wildlife Management 4(1):151-162; e1944-687X. doi: 10.3996/082012-JFWM-072

Copyright: All material appearing in the Journal of Fish and Wildlife Management is in the public domain and may be reproduced or copied without permission unless specifically noted with the copyright symbol $\odot$. Citation of the source, as given above, is requested.

The findings and conclusions in this article are those of the author(s) and do not necessarily represent the views of the U.S. Fish and Wildlife Service.

* Corresponding author: jeffrey_jolley@fws.gov 


\section{Introduction}

Aquatic invertebrate communities, including benthic macroinvertebrates and pelagic zooplankton, of temperate lakes have long been recognized as vital to the ecosystem function (Forbes 1925). They form a large part of the food web serving as vital links in energy pathways (Vadeboncoeur et al. 2002) linking primary producers and associated microorganisms to the fish community (Welker et al. 1994; Post et al. 1997; Bunnell et al. 2003). They also link aquatic and terrestrial ecosystems (DuBowy 1988; Werner et al. 1995; Cummins and Merritt 1996), ultimately affecting nutrient dynamics on a landscape scale (Kitchell et al. 1999). Therefore, assessing invertebrate communities in aquatic systems could provide insight into current lake states. Aquatic invertebrate communities vary in their diversity, density, and abundance among lakes that exist in alternative stable states (Blindow et al. 1993; Mallory et al. 1994; Bayley and Prather 2003; Van de Meutter et al. 2005). These alternative stable states in aquatic communities (Beisner et al. 2003) may exist as 1) clear water with low nutrients in the water column, low phytoplankton biomass, high aquatic macrophytes, and a diverse aquatic biota or 2) turbid water, high phytoplankton biomass, and limited submersed vegetation (Scheffer 1990; Scheffer et al. 1993; Hansel-Welch et al. 2003; Zimmer et al. 2003, 2009). In addition, lakes with intermediate nutrient levels may occur in either stable state, and the switch from one state to the other may follow different pathways depending on the direction of the shift, a phenomena termed hysteresis (Scheffer 1998; lbelings et al. 2007). Therefore the quantification of parameters that are characteristic of a stable state is often lake-specific, and the determination of lake state is made using an examination of the characteristics described above.

Many factors may play a role in affecting aquatic community structure, and fish may be central to influencing the ecosystem state (Carpenter et al. 1985; Carpenter and Kitchell 1988; Northcote 1988; Drenner and Hambright 2002). Planktivorous fish are often associated with the turbid water state by predation on zooplankton that, in turn, results in abundant phytoplankton through a top-down mechanism (Scheffer et al. 2001). Abundant piscivorious fish populations are often associated with the clear water state by predatory regulation of planktivorous fishes, thereby allowing zooplankton to proliferate and release the phytoplankton from top-down control (Spencer and King 1984; Carpenter et al. 1985; Scheffer et al. 1993; Duffy 1998; Ward et al. 2008). Furthermore, Diehl (1992) suggested that fish and macroinvertebrates could coexist in vegetated habitats by reducing foraging efficiency of fish. Alternatively, Paukert and Willis (2003a) summarized abundance estimates for zooplankton and macroinvertebrates in 30 Nebraska Sandhill lakes that contained fish communities. Relations among invertebrate abundances and physicochemical measures and vegetation coverage were found, whereas no relation between the fish community and invertebrate abundance was apparent.
The lack of relation between invertebrate abundance and fish community dynamics may indicate a bottom-up effect governed by nutrient availability or other indirect pathways (e.g., water level fluctuations) that may further explain these findings.

The invertebrate community is often evaluated to assess ecosystem health (Hilsenhoff 1987; Karr 1991; Rosenberg and Resh 1996) or fish community structure (Mills and Shiavone 1982; Mills et al. 1987). The aquatic invertebrate community is of seminal importance to the management goals of many lake ecosystems. For example, shallow lakes provide important breeding, brooding, and nursery habitats to economically important waterfowl species and shorebirds that rely on invertebrate populations as a major source of nutrition (Swanson and Nelson 1970; Bouffard and Hanson 1997; Cox et al. 1998). The Nebraska Sandhills are an important waterfowl production area (Bellrose 1980), and Valentine National Wildlife Refuge has specific wetland management objectives to maximize the food base (i.e., invertebrates and plants) for indigenous wildlife and migratory birds (U.S. Fish and Wildlife Service [USFWS] 1999). In addition, the refuge has a goal of maintaining sustainable and harvestable sport fish in those lakes where fishing is permitted. Thus, information regarding lake state and function can be obtained by collecting invertebrate and physicochemical data and ultimately used to evaluate these objectives. Furthermore, this information may aid with prioritization in space and time of management goals and actions.

In an effort to further understand lake-to-lake variability in form and function, we surveyed six lakes that we suspected may contain variable communities possibly related to different ecosystem states. Alternative lake states were defined as clear water (i.e., low phytoplankton, high macrophytes) or turbid water (high phytoplankton, low macrophytes). Our goals were to characterize lake invertebrate communities and physicochemical variables in six Nebraska Sandhill lakes and examine these characteristics within an alternative stable state framework. Our specific objectives related to lake form (i.e., objectives 1 and 2) and function (i.e., objectives 3 and 4) were to 1) compare macroinvertebrate and zooplankton densities and biomass among lakes; 2) compare physicochemical metrics among lakes; 3) use multivariate data reduction techniques to make inferences on related independent variables; and 4) describe and compare lake ecosystem state. Future decisions regarding priority and management can be evaluated based on these results.

\section{Methods}

Five lakes (within Sandhills ecoregion of north central Nebraska) were located on the Valentine National Wildlife Refuge in Cherry County and privately owned Cameron Lake in adjacent Rock County were sampled for water quality parameters in June and July 2005 (Table 1). Water levels are primarily governed by groundwater; surface runoff is minimal (Ginsberg 1985; Rundquist et al. 
Table 1. Descriptions of Nebraska Sandhill lakes sampled for aquatic invertebrates in 2005. Submergent vegetation coverage and year of observation was qualitatively assigned using existing literature; available source is given.

\begin{tabular}{lcccccc}
\hline Lake & $\begin{array}{c}\text { Surface } \\
\text { area }(\mathbf{h a})\end{array}$ & $\begin{array}{c}\text { Mean } \\
\text { depth }(\mathbf{m})\end{array}$ & $\begin{array}{c}\text { Maximum } \\
\text { depth }(\mathbf{m})\end{array}$ & $\begin{array}{c}\text { Vegetation } \\
\text { density }\end{array}$ & $\begin{array}{c}\text { Observation } \\
\text { year }\end{array}$ & Source \\
\hline Cameron & 39 & 1.8 & 2.9 & Low & 2005 & Jolley (2009) \\
McKeel & 19 & 0.9 & 1.6 & Low & 2005 & $\begin{array}{l}\text { J. C. Jolley, personal } \\
\text { observation }\end{array}$ \\
Pelican & 332 & 1.3 & 2.8 & High & 2005 & Jolley (2009) \\
Pony & 64 & 1.0 & 1.8 & Low & 2005 & Jolley and Willis (2009) \\
Rice & 19 & 1.2 & 1.7 & High & 2006 & Wanner (2007) \\
West Long & 25 & 1.3 & 1.8 & High & 2005 & Jolley et al. (2008) \\
\hline
\end{tabular}

1987). The lakes were generally stable throughout the study; they contained stable water levels throughout the year and experienced normal annual conditions (i.e., north-temperate climate). Winter kills of fish are uncommon due to flowing springs even though ice coverage may last up to 3 mo (McCarraher 1960).

The watersheds are primarily mixed- and tall-grass prairie, and livestock grazing is the principal land use (Bleed and Flowerday 1989). The lakes varied in surface area from 19 to 332 ha, were shallow (maximum depth 1.6-2.9 m), and almost entirely littoral (mean depth 0.9$1.8 \mathrm{~m}$ ). Submergent vegetation coverage in Sandhill lakes is variable, commonly ranging from approximately 15 to nearly 100\% (Paukert and Willis 2003a; Jolley 2009; Jolley and Willis 2009).

The study lakes contained fish communities common to Sandhill lakes, including bluegill Lepomis macrochirus, green sunfish Lepomis cyanellus, largemouth bass Micropterus salmoides, yellow perch Perca flavescens, northern pike Esox lucius, grass pickerel Esox americanus vermiculatus, common carp Cyprinus carpio, golden shiner Notemigonus crysoleucas, fathead minnow Pimephales promelas, and black bullhead Ameiurus melas. In addition, records of introduced Sacramento perch Archoplites interruptus in McKeel Lake exist from the 1970s (McCarraher and Gregory 1970). Angler exploitation was allowed on Pelican and Rice lakes and was presumably minimal (Paukert et al. 2002), and Cameron Lake was commercially harvested (i.e., modified fykenets) for adult yellow perch by the landowner. McKeel and Pony lakes were closed to fishing, and most of the lakes were remote and difficult to access. Vegetation coverage was described using published literature and agency reports, when available from the year of the study, for Cameron and Pelican (Jolley 2009), Pony and West Long (Jolley and Willis 2009), and Rice lakes (vegetation information was from the following year; Wanner 2007).

Invertebrates were sampled at 8 randomly chosen sites in Cameron Lake; 10 sites in Pelican Lake; and 4 sites each in McKeel, Pony, Rice, and West Long lakes. Site visits among lakes were unbalanced due to differing lake size (more sites were visited in the larger Pelican and Cameron lakes; Table 1). Two replicate benthic macroinvertebrate samples were collected using an Ekman dredge bottom sampler $\left(231 \mathrm{~cm}^{2}\right)$ at each site, strained through a 583- $\mu \mathrm{m}$ mesh sieve in the field, and stored in
$90 \%$ ethanol. Replicate samples were collected and processed separately. Macroinvertebrates were identified to order or class and enumerated using a dissecting microscope in the laboratory. In addition, midges were categorized as family Chironomidae or order Diptera for all other midges. The most common macroinvertebrate taxa were reported, and less common taxa were counted and expressed as taxa diversity. Individuals of all taxa combined were summed and expressed as totals at each site. Up to 20 individuals of each taxon were measured (total length in millimeters) per site, and all individuals were counted. Density was calculated by dividing the number of benthic invertebrates of each taxon by the area sampled with the Ekman dredge (i.e., $231 \mathrm{~cm}^{2}$ ). Macroinvertebrates also were collected from duplicate sweep net $(30.5 \times 25.4 \mathrm{~cm}$ net opening; $800-\mu \mathrm{m}$ bar mesh size) samples taken in the vegetation at each site or the closest patch of vegetation to the site. Sweep net catches were expressed as mean number per sweep net sample (only available for McKeel, Pony, Rice, and West Long lakes).

Zooplankton was collected during the daytime as two replicates at each site using a 2-m-long tube sampler (Rabeni 1996). Samples were filtered through a $65-\mu \mathrm{m}$ mesh net and stored in $90 \%$ ethanol. Zooplankton were enumerated and identified to family for cladocerans (i.e. Bosminidae, Chydoridae, and Daphnidae [Daphnia or Ceriodaphnia spp.]) and as cyclopoid (i.e., Cyclops spp.) and total copepods, copepod nauplii, class Ostracoda, and phylum Rotifera. Each sample was diluted with water to a measured volume of $30 \mathrm{~mL}$. Three subsamples were then taken with a 5-mL Hensen-Stempel pipette and placed in a Ward counting wheel. Up to 20 individuals of each category were measured (millimeters total length), and all individuals were counted. The total number of zooplankton of each taxon in a sample was calculated by dividing the number of organisms counted by the proportion of the sample volume processed. Density was then calculated by dividing the number of zooplankters of each taxon by the volume of the water filtered with the tube sampler. Zooplankton biomass was estimated using taxon-specific, length-dry weight equations (Mason 1977; McCauley and Kalff 1981; Culver et al. 1985; Lynch et al. 1986). Potential differences in mean invertebrate density, catch per sweep net, zooplankton density, and biomass among lakes were assessed using a nonparametric bootstrapping method (50,000 iterations, 
PROC MULTTEST; Westfall et al. 1999) because the multivariate assumptions of normality for ANOVA were rarely met. We also performed ANOVA on total macroinvertebrate density (all taxa combined) among lakes (data were log-transformed to meet the assumption of normality). Post hoc comparisons were performed using the Tukey multiple range test (Ruxton and Beauchamp 2008).

Phytoplankton biomass was indexed using chlorophyll- $a$ estimated from replicate water samples at each site using a 2-m-long tube sampler. Raw lake water $(100 \mathrm{~mL}$ ) was filtered (Whatman glass fiber filters, $0.45 \mu \mathrm{m})$ in the field and extracted in the laboratory following the methods described by Lind (1985). Duplicate samples of lake water were collected at each site and frozen; total phosphorous was determined following the methods of Wetzel and Likens (1991) in the laboratory. From the same sampling locations, total alkalinity was measured using a water chemistry analysis kit (Hach Company, Loveland, CO), and total dissolved solids were recorded $0.5 \mathrm{~m}$ below the surface using an electronic meter (Hach Company). Secchi disk transparency also was measured at each site. Physical and chemical parameters were compared with a nonparametric bootstrapping technique described above.

Analyses of the biotic and abiotic variables described above were performed to identify meaningful relationships among variables and to investigate potential differences among lakes. Factor analysis (PCAs with varimax rotation) was used to reduce the dimensionality of the data sets because of the large number of variables that were measured. The PCA was used to identify meaningful combined (i.e., created) variables. Independent variables and the subsequent PC groupings included benthic macroinvertebrate density (sweep net samples omitted due to lack of data for all lakes), zooplankton density and biomass, and physicochemical variables. Benthic macroinvertebrate and zooplankton variables included common taxa and combined categories (i.e., copepods, cladocerans, total benthic macroinvertebrates, and zooplankton). Physicochemical variables included measures of Secchi depth, conductivity, total dissolved solids, alkalinity, $\mathrm{pH}$, lake area, and lake depth. Principal components were retained based on a combination of the eigenvalue-one criteria (Kaiser 1960) and the proportion of variance method. Principal components with eigenvalues greater than 1.0 were retained until the cumulative proportion of variance accounted for by the PCs was greater than or equal to 0.70 (Stevens 2002). Variables that loaded ( $>40 \%$ ) on more than one factor were omitted in interpretation (Stevens 2002) because it is unclear which dimension these complex variables described. All statistical procedures were conducted using SAS software (SAS Institute 2002).

\section{Results}

The diversity and abundance of macroinvertebrates varied among lakes (Data S1, Supplemental Material). The diversity of taxa ranged from 2 to 8 for dredge samples and from 4 to 11 for sweep net samples. Specifically, for

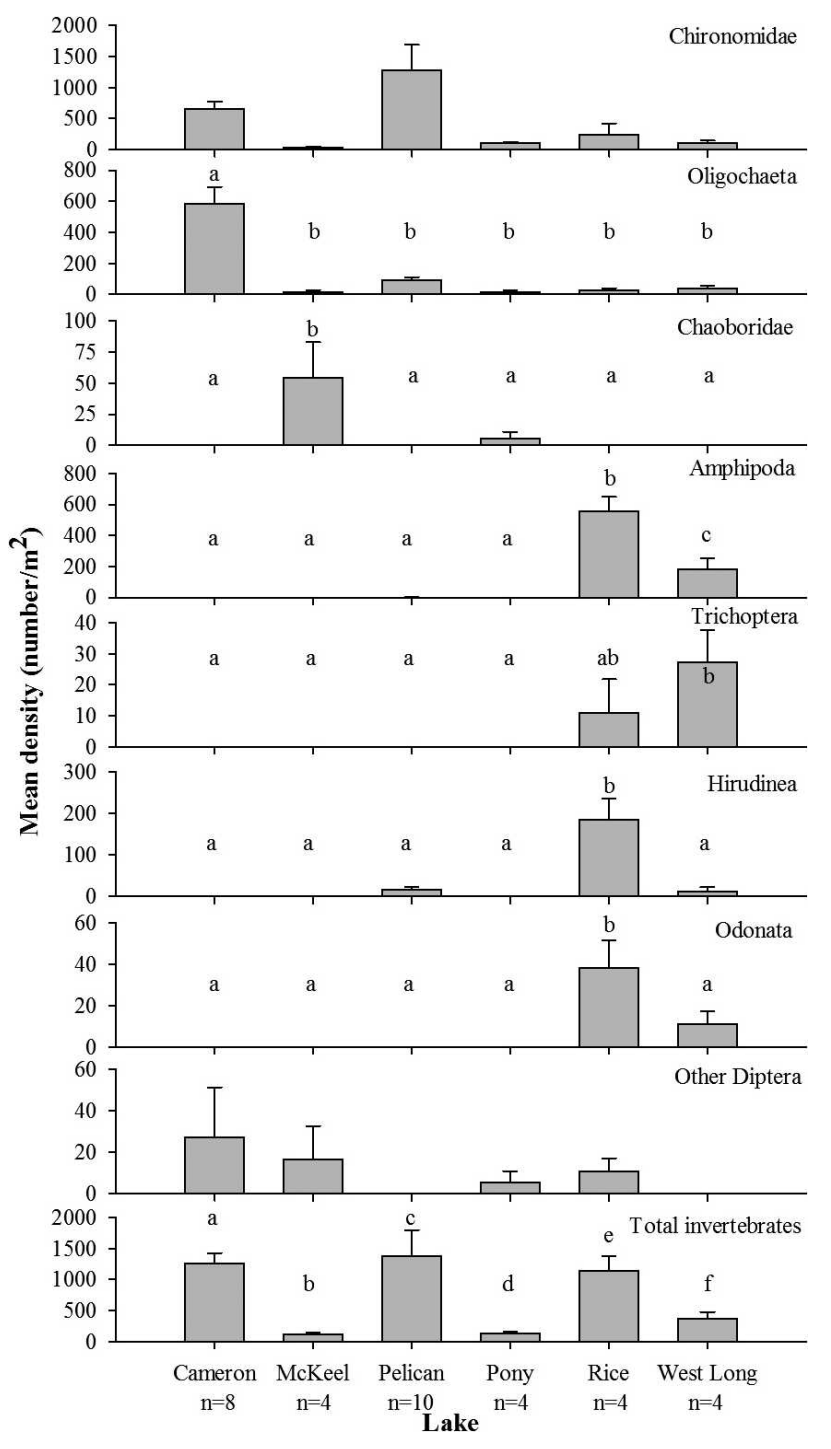

Figure 1. Mean density of common macroinvertebrate taxa collected in dredge samples in Nebraska Sandhill lakes in 2005. Different letters indicate significant differences (bootstrap procedure, $P<0.05$ ) among lakes, and vertical bars represent $1 \mathrm{SE}$ of the mean; bars without letters indicate no differences detected; $n$ denotes number of sites sampled in each lake.

dredge samples, Cameron Lake was the least diverse (taxa = 2), followed by McKeel (3), Pony (3), Pelican (4), West Long (6), and Rice (8) lakes. For sweep net samples, McKeel Lake was the least diverse (taxa $=4$ ), followed by Pony (5), Rice (10), and West Long (11) lakes. Sweep net samples were not available for Cameron or Pelican lakes. Total macroinvertebrate densities differed among lakes indexed by dredge $\left(F_{3,997} ; d f=5 ; P<0.05\right.$; Figure 1$)$ and sweep net samples $(P<0.05)$. Pelican (mean $=1,383$ invertebrates $\left./ \mathrm{m}^{2}, \mathrm{SE}=417\right)$ and Cameron lakes $(1,264$ invertebrates $/ \mathrm{m}^{2}, \mathrm{SE}=164$ ) had the highest total density indexed by dredge samples, whereas McKeel (120 invertebrates $/ \mathrm{m}^{2}, \mathrm{SE}=26$ ) and Pony (130 invertebrates $/ \mathrm{m}^{2}, \mathrm{SE}=31$ ) lakes had the lowest density. Total catch per sweep net sample was higher in Rice Lake than McKeel or Pony lakes. Multiple differences in individual 


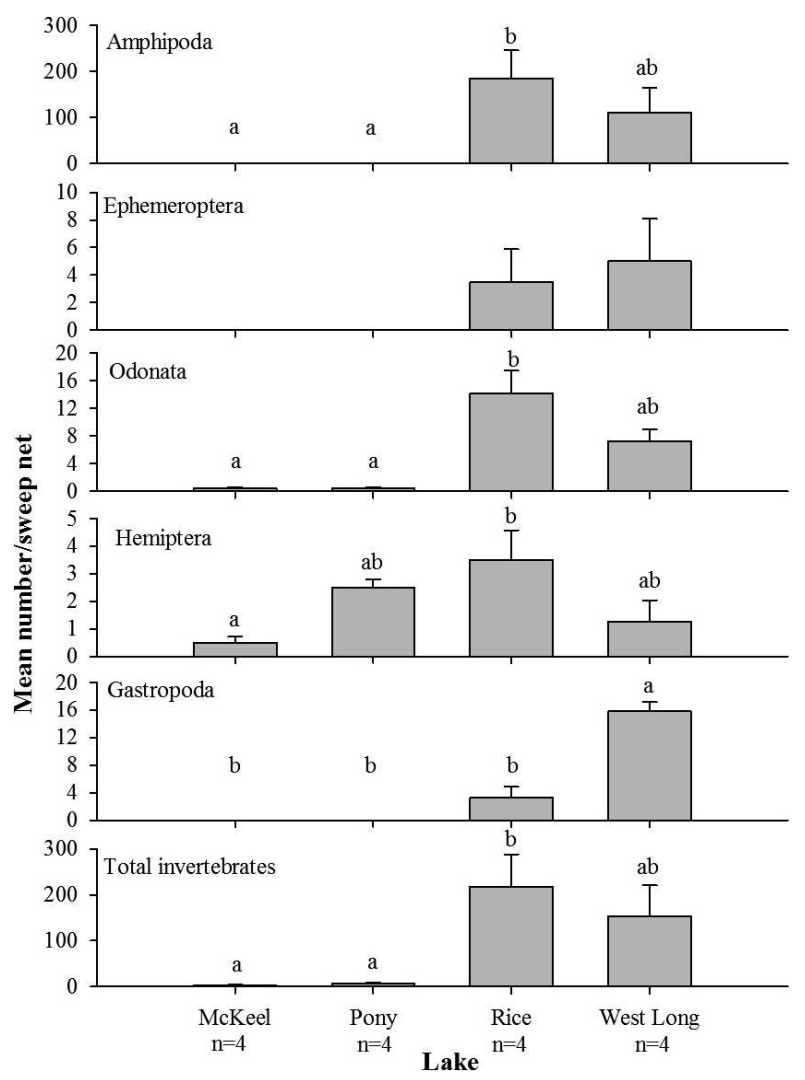

Figure 2. Mean catch of common macroinvertebrate taxa collected in sweep net samples in Nebraska Sandhill lakes in 2005. Different letters indicate significant differences (bootstrap procedure, $P<0.05$ ) among lakes, and vertical bars represent 1 SE of the mean; bars without letters indicate no differences detected; $\mathrm{n}$ denotes number of sites sampled in each lake.

taxa abundance among lakes were detected in dredge and sweep net samples (Figures 1 and 2). Most notably, Rice Lake often had a higher abundance of invertebrates, followed by West Long Lake, whereas McKeel and Pony lakes often had depressed abundances. McKeel Lake had relatively high-to-moderate abundances of chaoborids and hemipterans, and Cameron Lake had the highest density of oligochaetes (Figures 1 and 2).

Mean total zooplankton density ranged from 201 to 3,491 zooplankters/L, and dominant taxa varied among lakes (Figure 3). Differences were detected among lakes for all taxa examined except ostracods. Pony Lake had the highest density of total zooplankton as well as Bosmina spp., cladocerans, nauplii, and rotifers. Cameron Lake was dominated by Daphnia spp., whereas Rice Lake had high densities of Ceriodaphnia spp. and Chydorus spp. Copepods were most abundant in Pony and Rice lakes.

Patterns in zooplankton biomass were largely similar to those of zooplankton density (Figure 4). Overall biomass was greatest in Cameron Lake (largely driven by Daphnia spp.), lowest in McKeel Lake, and moderate in the other lakes (Table 2). Cameron and Pelican lakes were dominated by Daphnia spp., McKeel Lake was dominated by nauplii, and Pony Lake was dominated by Bosmina spp. Rice and West Long lakes had a more

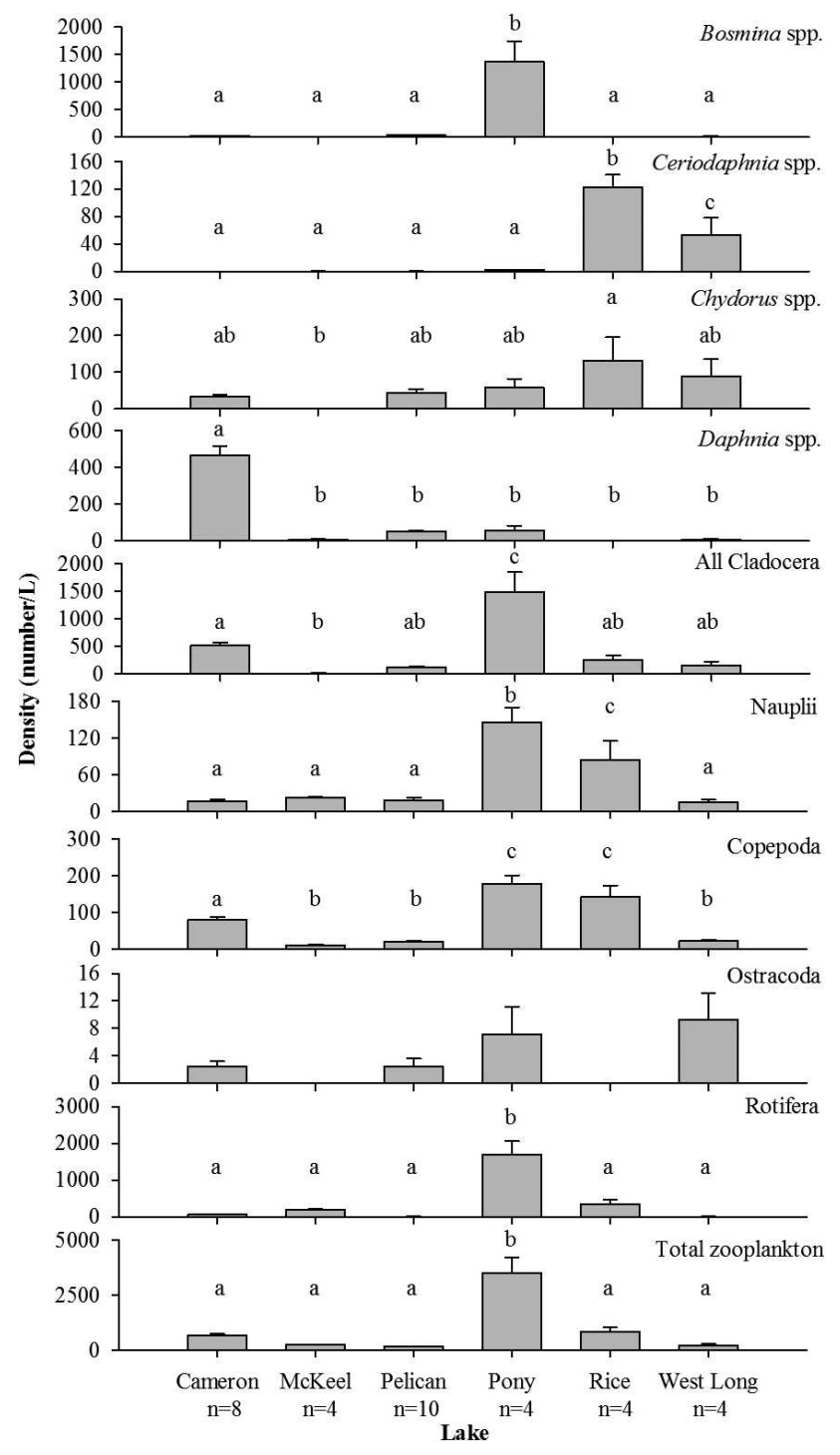

Figure 3. Mean density of zooplankton taxa from Nebraska Sandhill lakes in 2005. Different letters indicate significant differences (bootstrap procedure, $P<0.05$ ) among lakes, and vertical bars represent $1 \mathrm{SE}$ of the mean; bars without letters indicate no differences detected; $n$ denotes number of sites sampled in each lake.

balanced biomass of several taxa of zooplankton (Figure 4), although copepods were more abundant here than in the other lakes.

Water quality parameters exhibited a spectrum of conditions among the lakes (Figure 5). Mean Secchi depth ranged from 16 to $160 \mathrm{~cm}$ and was highest in Rice and West Long lakes (water clarity was often to the lake bottom), moderate in Pelican (mean $=78 \mathrm{~cm}, \mathrm{SE}=7 \mathrm{~cm}$ ) and Cameron lakes (mean $=57 \mathrm{~cm}, \mathrm{SE}=5 \mathrm{~cm}$ ), and the lowest in McKeel $($ mean $=16 \mathrm{~cm}, \mathrm{SE}=2 \mathrm{~cm})$ and Pony lakes $($ mean $=16 \mathrm{~cm}, \mathrm{SE}=1 \mathrm{~cm}$ ). Chlorophyll- $a$ was also variable and ranged from 5 to $192 \mu \mathrm{g} / \mathrm{L}$. Chlorophyll- $a$ was significantly higher in McKeel and Pony lakes than in the other lakes (Figure 5). Total phosphorous ranged from 18.5 to $50.9 \mu \mathrm{g} / \mathrm{L}$ and was significantly higher in West Long Lake than in the other lakes. Alkalinity ranged from 120 to 


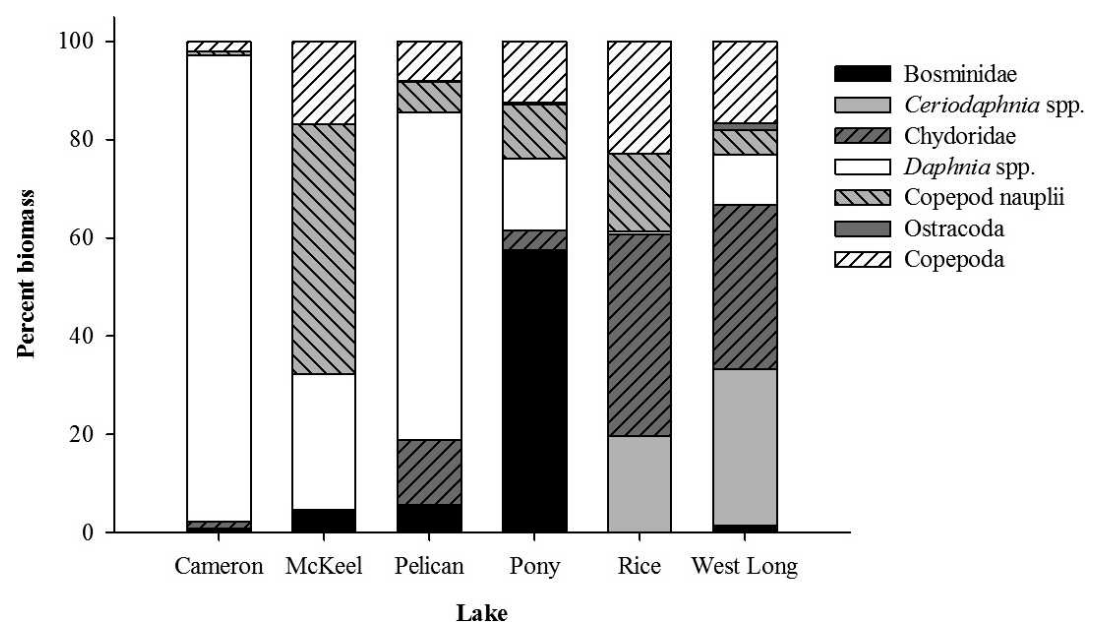

Figure 4. Percent biomass of zooplankton taxa in six Nebraska Sandhill lakes in 2005.

$385 \mathrm{mg} / \mathrm{L} \mathrm{CaCO}_{3}$ and multiple statistical differences were detected (Figure 5). McKeel Lake was the most alkaline and Cameron Lake was the least alkaline.

The PCA indicated that the first three PCs explained $79 \%$ of variability. The PC1 was interpreted primarily as an index of macroinvertebrate taxa density and density and biomass of small zooplankters (Ceriodaphnia and Chydorus spp.). The PC2 was interpreted primarily as an index of small-bodied zooplankter density. The PC3 was interpreted as an index of the biomass of Daphnia, all Cladocera combined, and total zooplankton biomass as well as total density of macroinvertebrates (Table 3).

Physical, biological, and chemical parameters varied widely in these lakes and were placed in a gradient of alternative ecosystem states (Figure 6). Rice and West Long lakes displayed the clear water state, high invertebrate abundance and diversity, and low phytoplankton as indexed by chlorophyll- $a$. These lakes also had high submergent aquatic macrophyte coverage (Jolley 2009). McKeel and Pony lakes were at the opposite end of the spectrum, with turbid water (low water clarity due to abundant phytoplankton), low invertebrate abundance and diversity, high levels of phytoplankton, and low vegetation coverage (Jolley 2009). Cameron and Pelican lakes were intermediate
(Figure 6) to the other lakes, with moderate levels of many metrics examined.

\section{Discussion}

Alternative ecosystem states were identified in these Sandhill lakes and existed across a gradient from clear water to turbid water, with two lakes intermediate and in a possible state of hysteresis (Scheffer et al. 1993, 2001; Beisner et al. 2003). The lakes studied were all in proximity; refuge lakes were all within $19 \mathrm{~km}$ and Cameron Lake was located $109 \mathrm{~km}$ from the refuge lakes. Although this study lacks a temporal component to assess the stability of conditions in these lakes, a wide range of conditions were observed, providing evidence for different lake form and function across these Sandhill lakes.

Our ordinations revealed meaningful groupings that followed lake-specific patterns. Variables associated with a lake in the clear water state (Scheffer et al. 1993) loaded similarly (i.e., Secchi depth and abundance of benthic invertebrate taxa associated with aquatic vegetation). In addition, density and biomass of the small-bodied Ceriodaphnia and Chydorus species also loaded similarly and were abundant in the clear water lakes Rice and

Table 2. Mean (and SE in parentheses) estimated biomass ( $\mu \mathrm{g} / \mathrm{L}$ ) of zooplankton taxa in Nebraska Sandhill lakes in 2005. Results of one-way ANOVA among lakes for each taxa are given as $F$ statistic, degrees of freedom ( $d f$ ), and associated $P$ value. Different letters indicate significant differences among lakes for each taxa.

\begin{tabular}{|c|c|c|c|c|c|c|c|c|c|}
\hline Lake & Bosminidae & $\begin{array}{l}\text { Ceriodaphnia } \\
\text { spp. }\end{array}$ & Chydoridae & $\begin{array}{l}\text { Daphnia } \\
\text { spp. }\end{array}$ & Nauplii & Ostracoda & $\begin{array}{c}\text { All } \\
\text { cladocerans }\end{array}$ & $\begin{array}{c}\text { All } \\
\text { copepods }\end{array}$ & Total \\
\hline Cameron & 19.0 (2.9)b & $0.0(-) b$ & 33.4 (3.9)b & $2,323.4$ (259.4)a & $16.0(2.9) b$ & $1.1(0.3) a b$ & $2,375.7$ (260.5)a & $51.0(5.0) \mathrm{b}$ & 2,442.7 (266.8)a \\
\hline McKeel & $2.0(0.4) b$ & $0.1(0.1) b$ & $0.0(-) \mathrm{b}$ & 11.9 (3.7)b & $22.0(0.7) b$ & $0.0(-) b$ & 13.9 (3.4)b & $7.3(1.0) b$ & $43.3(4.1) c$ \\
\hline Pelican & $19.2(2.5) b$ & $0.05(0.05) b$ & $45.8(10.4) b$ & $229.2(35.3) b$ & $20.8(5.2) b$ & $1.2(0.5) a b$ & $294.2(34.8) b$ & 27.5 (3.8)b & 339.4 (34.7)bc \\
\hline Pony & $556.0(154.4) a$ & $1.2(0.2) b$ & $40.3(17.1) b$ & $140.9(69.7) b$ & 107.8 (17.8)a & 3.1 (1.8)ab & 738.4 (129.6)b & $121.2(16.5) a$ & 967.4 (140.8)b \\
\hline Rice & $0.0(-) b$ & 93.0 (13.5)a & $194.3(95.4) a$ & $2.7(2.7) b$ & 75.0 (27.8)a & $0.0(-) b$ & $290.1(106.2) b$ & $108.5(24.2) a$ & 473.5 (124.8)bc \\
\hline West Long & $4.5(4.5) b$ & 88.3 (41.0)a & 93.6 (49.3)ab & $28.2(25.6) b$ & 13.9 (3.5)b & 4.1 (1.7)a & $214.6(98.0) b$ & 46.7 (10.5)b & 275.2 (108.5)bc \\
\hline$F$ & 21.15 & 13.10 & 3.77 & 44.13 & 12.27 & 3.19 & 36.45 & 18.56 & 34.30 \\
\hline$d f$ & 5 & 5 & 5 & 5 & 5 & 5 & 5 & 5 & 5 \\
\hline$P$ & $<0.01$ & $<0.01$ & 0.01 & $<0.01$ & $<0.01$ & 0.02 & $<0.01$ & $<0.01$ & $<0.01$ \\
\hline
\end{tabular}



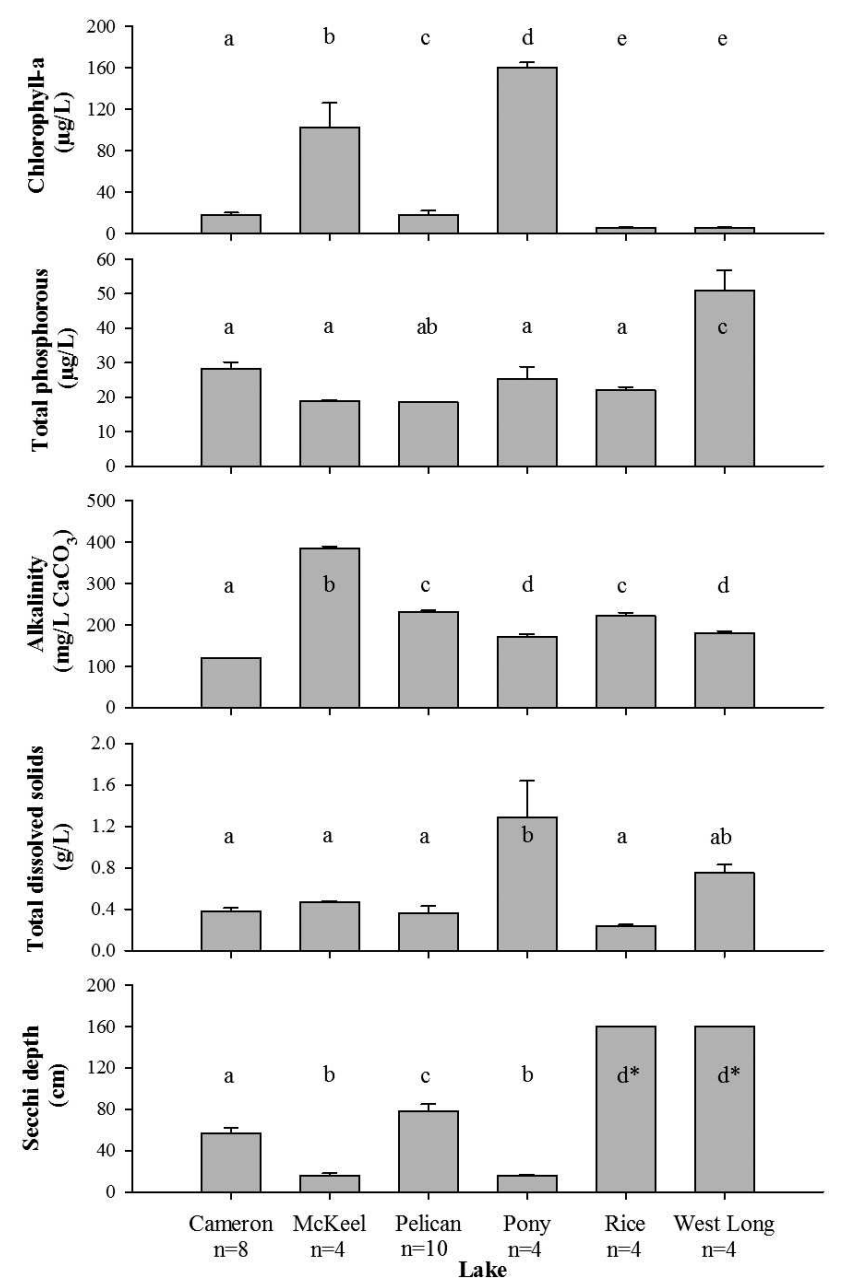

Figure 5. Mean values of physicochemical measures from Nebraska Sandhill lakes in 2005. Different letters indicate significant differences (bootstrap procedure, $P<0.05$ ) among lakes, and vertical bars represent 1 SE of the mean; bars without letters indicate no differences detected; $n$ denotes number of sites sampled in each lake. Asterisk $\left(^{*}\right)$ indicates that Secchi depth was greater than the bottom depth at all sites, and vertical bars represent $1 \mathrm{SE}$ of the mean.

West Long. Paukert and Willis (2003a) also found that Ceriodaphnia spp. associated with submersed vegetation but not Chydorus spp. Variables associated with a lake in the turbid water state also loaded similarly (i.e., density and biomass of nondaphnid smaller-bodied zooplankters and total dissolved solids). Small-bodied zooplankters have been previously associated with eutrophic lakes (Bays and Chrisman 1983) but not related to productivity in others (Pace 1986).

The lakes studied had varied fish communities, and this variation may have influenced the invertebrate and zooplankton communities. Rice and West Long lakes had fish populations consisting of abundant piscivorous largemouth bass and northern pike (Jolley et al. 2008; Jolley 2009). Furthermore, Rice Lake had a direct connection to Duck Lake that contained bluegill, yellow perch, and largemouth bass (Paukert and Willis 2003b; Jolley 2009), species that were also observed in 2005 (i.e., largemouth bass, J. C. Jolley, USFWS, personal observation). The lakes with these fish communities (i.e., piscivore dominated) had relatively clear water, dense vegetation, high invertebrate abundance, and low phytoplankton levels. These characteristics are likely influenced by the fish community (Ward et al. 2008). Cameron Lake contained abundant planktivores consisting of yellow perch and fathead minnows and the benthivorous common carp (Jolley et al. 2010); Pelican Lake also had abundant bluegill, yellow perch, and common carp but also contained piscivorous northern pike and largemouth that likely mediated the planktivore population. Pony Lake contained abundant fathead minnows, common carp, and black bullhead that made up 94\% of the fish standing stock (Jolley and Willis 2009). The fish community of McKeel Lake was unknown and recent survey data are nonexistent. Studies from the late 1960s and early 1970s indicated fathead minnow and Sacramento perch were present (McCarraher and Thomas 1968; McCarraher and Gregory 1970). McKeel Lake displayed characteristics most similar to Pony Lake, which was dominated by planktivores.

Fish communities can have varied effects on invertebrate communities. Overly abundant yellow perch can reduce size structure of zooplankton and macroinvertebrates (Lott et al. 1996, 1998), and a similar situation may exist in Pony Lake with its abundant planktivores and invertivores. Fishes can affect benthic invertebrate populations (Crowder and Cooper 1982; Lott 1991; Zimmer et al. 2001), although effects may be mixed (Gilinsky 1984). Finally, the presence of the benthivorous common carp may further influence the results. Common carp can have mixed influences on aquatic communities (Parkos et al. 2003) but have been most noted to negatively affect aquatic macrophytes (Chamberlain 1948; Crivelli 1983; Fletcher et al. 1985; Kolterman 1990). Common carp can influence the invertebrate community (Parkos et al. 2003; Stewart and Downing 2008) by direct consumption or typically by reducing complex invertebrate habitat provided by macrophyte beds. Common carp were present in Cameron, Pelican, and Pony lakes (all of which had moderate-to-low macroinvertebrate communities) and were absent in West Long and Rice lakes (both of which had abundant macroinvertebrate communities).

The zooplankton communities among lakes were more complex as different suites of species dominated on a lake-by-lake basis. Cameron Lake was dominated by large-bodied Daphnia spp. (sample taken in June), and many lakes experience a midsummer decline in Daphnia spp. abundance (Kaemingk et al. 2012). Cameron Lake did not display this decline in 2005, but it was observed in 2004, and may be attributed to a weak year-class of the planktivorous yellow perch (Jolley et al. 2010). Predation on Daphnia spp. by yellow perch has been reported previously (Whiteside et al. 1985; Prout et al. 1990), and this predation may explain the relative dearth of Daphnia spp. in most lakes (Kaemingk et al. 2012). Small-bodied zooplankters may have flourished due to a competitive release from the absence of Daphnia spp. McKeel Lake had a relatively depressed zooplankton 
Table 3. Results of factor analysis (i.e., PCA with varimax rotation) of independent variables measured in Sandhill lakes in 2005. Factor scores with an asterisk $\left(^{*}\right)$ were those selected for the factor (loadings $>40$ ). Variables that loaded $(>40)$ on more than one factor were omitted in interpretation.

\begin{tabular}{|c|c|c|c|c|}
\hline Category & Variable & PC1 & PC2 & PC3 \\
\hline \multirow[t]{9}{*}{ Zooplankton density } & Bosmina spp. & -26 & $95^{*}$ & -10 \\
\hline & Ceriodaphnia spp. & $98^{*}$ & -4 & -15 \\
\hline & Chydorus spp. & $95^{*}$ & 18 & -6 \\
\hline & Daphnia spp. & -23 & -6 & $97^{*}$ \\
\hline & All cladocerans & -17 & $95^{*}$ & 20 \\
\hline & Nauplii & 19 & $96^{*}$ & -16 \\
\hline & All copepods & 38 & $89^{*}$ & 20 \\
\hline & Rotifers & -12 & $97^{*}$ & -14 \\
\hline & Total & -10 & $98^{*}$ & 3 \\
\hline \multirow[t]{7}{*}{ Zooplankton biomass } & Bosmina spp. & -27 & $94^{*}$ & -8 \\
\hline & Ceriodaphnia spp. & $88^{*}$ & -18 & -19 \\
\hline & Chydorus spp. & $99^{*}$ & 5 & -7 \\
\hline & Daphnia spp. & -21 & -11 & $97^{*}$ \\
\hline & All cladocerans & -16 & 12 & $98^{*}$ \\
\hline & Nauplii & 27 & $93^{*}$ & -18 \\
\hline & Total & -12 & 20 & $97^{*}$ \\
\hline \multirow[t]{5}{*}{ Physicochemical } & Mean depth & 11 & -30 & $90^{*}$ \\
\hline & Secchi depth & $85^{*}$ & -35 & -5 \\
\hline & Alkalinity & -24 & -33 & -70 \\
\hline & Dissolved oxygen & 12 & 0 & $-85^{*}$ \\
\hline & Total dissolved solids & -34 & $74^{*}$ & -20 \\
\hline \multirow[t]{7}{*}{ Macroinvertebrate density } & Order Amphipoda & $98^{*}$ & -2 & -13 \\
\hline & Order Trichoptera & $55^{*}$ & -31 & -20 \\
\hline & Order Odonata & $97^{*}$ & -1 & -13 \\
\hline & Order Diptera & -13 & -11 & $70^{*}$ \\
\hline & Class Oligochaeta & -18 & -19 & 96 \\
\hline & Class Hirudinea & $92^{*}$ & 5 & -10 \\
\hline & Total & 34 & -31 & $51 *$ \\
\hline
\end{tabular}

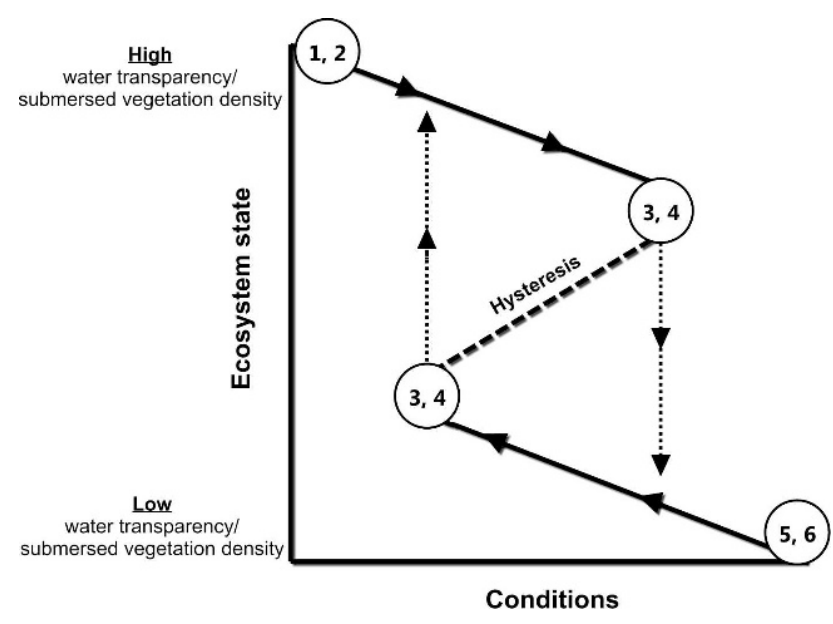

Figure 6. Continuum of ecosystem states for six Nebraska Sandhill lakes in 2005: Rice and West Long (1 and 2), Pelican and Cameron (3 and 4), and McKeel and Pony (5 and 6). Lakes at ends of the continuum may be in a stable state, whereas intermediate lakes (Cameron and Pelican) may be in hysteresis. Figure adapted from Scheffer et al. (2001). community, whereas Pony Lake had a community dominated by small-bodied zooplankters (i.e., Bosmina spp. and copepod nauplii). Rice and West Long lakes contained different small-bodied cladocerans (i.e., Ceriodaphnia spp. and Chydorus spp.).

Patterns observed relating to zooplankton and benthic invertebrates in these lakes could be related to bottomup processes as opposed to top-down processes (i.e., fish). Water level fluctuations in these systems could influence primary productivity by releasing nutrients into each system (McEwen and Butler 2010) as a result of groundwater or precipitation events. These nutrients could influence higher trophic levels, such as invertebrate communities. Paukert and Willis (2003a) found some support for this notion; however, limited information exists on how natural lakes respond to water level fluctuations (Coops et al. 2003; Wantzen et al. 2008). Our study provides empirical data on biotic and abiotic conditions in lakes located on the Valentine National Wildlife Refuge and the first data on McKeel and Rice lakes in recent history. This knowledge of community state may help managers reach competing, but not mutually exclusive, goals of waterfowl production and 
quality sport fish populations. For example, Cox et al. (1998) found the abundance of aquatic macroinvertebrates was positively related to growth and survival of mallard Anas platyrhynchos ducklings. Furthermore, fishes can compete with waterfowl, especially broods, for invertebrates (Swanson and Nelson 1970; Bouffard and Hanson 1997). Hanson and Riggs (1995) found that fathead minnows reduced abundance and biomass of insects and crustaceans in wetlands to the extent that the suitability of these habitats was reduced as seasonal foraging areas for waterfowl. Hill et al. (1987) found lower survival of mallard ducklings in lakes with high densities of fish compared with those feeding in riverine habitats with lower densities of fish. Alternatively, piscivorous fish populations may mitigate the effect of abundant planktivores. Ward et al. (2008) reported walleye fry stockings could suppress fathead minnow populations in wetlands, and the invertebrate communities in walleye-dominated wetlands were more abundant than those dominated by fathead minnows. Nevertheless, shallow lakes and wetlands containing dense invertebrate communities are of conservation interest by waterfowl managers (Cox et al. 1998). Specifically, the Comprehensive Conservation Plan for the Valentine National Wildlife Refuge states goals of maximizing invertebrate and plant food resources to provide an appropriate food base for indigenous wildlife including migratory birds (USFWS 1999). In addition, goals of providing an unexploited food base for lakes not designated for sport fishing (i.e., McKeel and Pony) and maintaining sustainable and harvestable populations of sport fish in those lakes open to recreational fishing (i.e., Pelican, West Long, and Rice) can be achieved, in part, with rich invertebrate communities.

Multiple small lakes, in proximity, displaying alternate ecosystem states invites the opportunity for more indepth analyses of driving mechanisms. In addition, separating the effect of common carp populations from planktivorous fishes in these lakes warrants further study. Future work coupling comprehensive empirical data on multiple variables (i.e., fish, macrophytes, invertebrates, and physical measures) may be valuable to address these complex management questions (Jolley and Willis 2009).

\section{Supplemental Material}

Please note: The Journal of Fish and Wildlife Management is not responsible for the content or functionality of any supplemental material. Queries should be directed to the corresponding author for the article.

Reference S1. Jolley JC. 2009. Recruitment of bluegill and yellow perch in Nebraska Sandhill lake: integrating multiple life stages. Doctoral dissertation. South Dakota State University, Brookings.

Found at DOI: http://dx.doi.org/10.3996/082012-JFWM072.S1; also available at http://pubstorage.sdstate.edu/ wfs/thesis/Jolley-Jeffrey-C-Ph-D-2009.pdf (721 KB PDF).

Reference S2. Jolley JC and Willis DW. 2009. Biotic communities in Nebraska Sandhill lakes. Nebraska Game and Parks Commission, Lincoln.
Found at DOI: http://dx.doi.org/10.3996/082012-JFWM072.S2 (450 KB PDF).

Reference S3. Kolterman BF. 1990. Effects of common carp and black bullheads on sago pondweed. Master's thesis. South Dakota State University, Brookings.

Found at DOI: http://dx.doi.org/10.3996/082012-JFWM072.S3; also available at http://pubstorage.sdstate.edu/ wfs/thesis/Kolterman-Bret-F-M-S-1990.pdf (7162 KB PDF).

Reference S4. Lott JP. 1991. Food habits of yellow perch in eastern South Dakota glacial lakes. Master's thesis. South Dakota State University, Brookings.

Found at DOI: http://dx.doi.org/10.3996/082012-JFWM072.S4; also available at http://pubstorage.sdstate.edu/ wfs/thesis/Lott-John-P-MS-1991.pdf (13.8 MB PDF).

Reference S5. McCarraher DB. 1960. The Nebraska Sandhill lakes: their characteristics and fisheries management problems. Nebraska Game and Parks Commission, White Papers, Conference Presentations, and Manuscripts, Paper 7.

Found at DOI: http://dx.doi.org/10.3996/082012-JFWM072.S5; also available at http://digitalcommons.unl.edu/cgi/ viewcontent.cgi?article $=1006 \&$ context $=$ nebgamewhitepap (442 KB PDF).

Reference S6. Wanner GA. 2007. 2007 fishery assessment surveys conducted on the Valentine National Wildlife Refuge. 2007 Annual Report, USFWS, Pierre, South Dakota.

Found at DOI: http://dx.doi.org/10.3996/082012-JFWM072.S6; also available at http://www.fws.gov/greatplains fishandwildlife/documents/2007ValentineNWRFisheryReport. pdf (1005 KB PDF).

Data S1. Macroinvertebrate, zooplankton, and physical parameter data from six Nebraska Sandhill lakes in 2005.

Found at DOI: http://dx.doi.org/10.3996/082012-JFWM$072 . S 7$ (107 KB XLSX).

\section{Acknowledgments}

We thank J. Rydell, A. Kvien, and C. Symens for field and laboratory assistance. M. Lindvall and Valentine National Wildlife Refuge provided access to refuge lakes, and $\mathrm{R}$. Lackaff provided access to Cameron Lake. We thank D. Graham, D. Hartmann, D. Kruger, and the Valentine State Fish Hatchery for assistance. K. Herrington provided valuable comments on an earlier draft of this manuscript. We also thank the three anonymous reviewers and the Subject Editor for valuable improvement to this manuscript.

Funding for this project was provided by the Nebraska Game and Parks Commission through Federal Aid in Sport Fish Restoration Project F-118-R. Funding for this project was provided by the Nebraska Game and Parks Commission through Federal Aid in Sport Fish Restoration Project F-118-R.

Any use of trade, product, or firm names is for descriptive purposes only and does not imply endorsement by the U.S. Government. 


\section{References}

Bayley SE, Prather CM. 2003. Do wetland lakes exhibit alternative stable states? Submersed aquatic vegetation and chlorophyll in western boreal shallow lakes. Limnology and Oceanography 48:2335-2345.

Bays JS, Crisman TL. 1983. Zooplankton and trophic state relationships in Florida lakes. Canadian Journal of Fisheries and Aquatic Sciences 40:1813-1819.

Beisner BE, Haydon DT, Cuddington K. 2003. Alternative stable states in ecology. Frontiers in Ecology and the Environment 1:376-382.

Bellrose FS. 1980. Ducks, geese, and swans of North America. Harrisburg, Pennsylvania: Stockpole Books.

Bleed A, Flowerday C. 1989. Introduction. Pages 1-15 in Bleed A, Flowerday C, editors. An atlas of the Sand Hills. Lincoln: University of Nebraska.

Blindow IG, Andersson G, Hargeby A, Johansson S. 1993. Long-term pattern of alternative stable states in two shallow eutrophic lakes. Freshwater Biology 30:159167.

Bouffard SH, Hanson MA. 1997. Fish in waterfowl marshes: waterfowl managers' perspective. Wildlife Society Bulletin 25:146-157.

Bunnell DB, Gonzalez MJ, Stein RA. 2003. Zooplankton biomass enhances growth, but not survival, of firstfeeding Pomoxis spp. larvae. Canadian Journal of Fisheries and Aquatic Sciences 60:1314-1323.

Carpenter SR, Kitchell JF. 1988. Consumer control of lake productivity. Bioscience 38:764-769.

Carpenter SR, Kitchell JF, Hodgson JR. 1985. Cascading trophic interactions and lake productivity. Bioscience 35:634-639.

Chamberlain EB. 1948. Ecological factors influencing the growth and management of certain waterfowl food plants on Back Bay National Wildlife Refuge. Transactions North American Wildlife Conference 13:347356.

Coops H, Beklioglu M, Crisman T. 2003. The role of water-level fluctuations in shallow lake ecosystems workshop conclusions. Hydrobiologia 506-509:2327.

Cox RR Jr, Hanson MA, Roy CC, Euliss NH Jr, Johnson DH, Butler MG. 1998. Mallard duckling growth and survival in relation to aquatic invertebrates. Journal of Wildlife Management 62:124-133.

Crivelli AJ. 1983. The destruction of aquatic vegetation by carp. Hydrobiologia 106:37-41.

Crowder LB, Cooper WE. 1982. Habitat structural complexity and the interaction between bluegills and their prey. Ecology 63:1802-1813.

Culver DA, Boucherle MM, Bean DJ, Fletcher JW. 1985. Biomass of freshwater crustacean zooplankton from length-weight regressions. Canadian Journal of Fisheries and Aquatic Sciences 42:1380-1390.

Cummins KW, Merritt RM. 1996. Ecology and distribution of aquatic insects. Pages 74-86 in Merritt RW, Cummins KW, editors. An introduction to the aquatic insects of North America. 3rd edition. Dubuque, lowa: Kendall Hunt.
Diehl S. 1992. Fish predation and benthic community structure: the role of omnivory and habitat complexity. Ecology 73:1646-1661.

Drenner RW, Hambright KD. 2002. Piscivores, trophic cascades, and lake management. Scientific World Journal 2:284-307.

DuBowy PJ. 1988. Waterfowl communities and seasonal environments: temporal variability in interspecific competition. Ecology 69:1439-1453.

Duffy WG. 1998. Population dynamics, production, and prey consumption of fathead minnows (Pimephales promelas) in prairie wetlands: a bioenergetics approach. Canadian Journal of Fisheries and Aquatic Sciences 54:15-27.

Fletcher AR, Morrison AK, Hume DJ. 1985. Effects of carp, Cyprinus carpio L., on communities of aquatic vegetation and turbidity of waterbodies in the lower Goulburn River Basin. Australian Journal of Marine and Freshwater Research 36:311-327.

Forbes SA. 1925. The lake as a microcosm. Bulletin of the Illinois Natural History Survey 15:537-550.

Gilinsky E. 1984. The role of fish predation and spatial heterogeneity in determining benthic community structure. Ecology 65:455-468.

Ginsberg M. 1985. Nebraska's Sandhills lakes: a hydrogeological overview. Water Resources Bulletin 21:573578.

Hansel-Welch N, Butler MG, Carlons, TJ, Hanson MA. 2003. Changes in macrophyte community structure in Lake Christina (Minnesota), a large shallow lake, following biomanipulation. Aquatic Botany 75:323-337.

Hanson MA, Riggs MR. 1995. Potential effects of fish predation on wetland invertebrates: a comparison of wetlands with and without fathead minnows. Wetlands 15:167-175.

Hill D, Wright R, Street M. 1987. Survival of mallard ducklings Anas platyrhynchos and competition with fish for invertebrates on a flooded gravel quarry in England. Ibis 129:159-167.

Hilsenhoff WL 1987. An improved biotic index of organic stream pollution. Great Lakes Entomologist 20:31-36.

Ibelings BW, Portielje R, Lammens EHRR, Noordhuis R, van den Berg MS, Joosse W, Meijer ML. 2007. Resilience of alternative stable states during the recovery of shallow lakes from eutrophication: Lake Veluwe as a case study. Ecosystems 10:4-16.

Jolley JC, Willis DW, DeBates TJ, Graham DD. 2008. The effects of mechanically reducing northern pike density on the sport fish community of West Long Lake, Nebraska, USA. Fisheries Management and Ecology 15:251-258.

Jolley JC. 2009. Recruitment of bluegill and yellow perch in Nebraska Sandhill lake: integrating multiple life stages. Doctoral dissertation. Brookings: South Dakota State University (see Supplemental Material, Reference S1, http://dx.doi.org/10.3996/082012-JFWM-072.S1); also available: http://pubstorage.sdstate.edu/wfs/thesis/Jol ley-Jeffrey-C-Ph-D-2009.pdf (November 2012). 
Jolley JC, Willis DW. 2009. Biotic communities in Nebraska Sandhill lakes. Lincoln: Nebraska Game and Parks Commission (see Supplemental Material, Reference S2, http://dx.doi.org/10.3996/082012-JFWM-072. S2).

Jolley JC, Willis DW, Holland RS. 2010. Match-mismatch regulation for bluegill and yellow perch larvae and their prey in Sandhill lakes. Journal of Fish and Wildlife Management 1:73-85.

Kaemingk MA, Jolley JC, Willis DW, Chipps SR. 2012. Priority effects among young-of-the-year fish: reduced growth of bluegill sunfish (Lepomis macrochirus) caused by yellow perch (Perca flavescens)? Freshwater Biology 57:654-665.

Kaiser HF. 1960. The application of electronic computers to factor analysis. Educational and Psychological Measurement 20:141-151.

Karr JR. 1991. Biological integrity: a long-neglected aspect of water resource management. Ecological Applications 1:66-84.

Kitchell JF, Schindler DE, Herwig BR, Post DM, Olson MH, Oldham M. 1999. Nutrient cycling at the landscape scale: the role of diel foraging migrations by geese at the Bosque del Apache National Wildlife Refuge, New Mexico. Limnology and Oceanography 44:828-836.

Kolterman BF. 1990. Effects of common carp and black bullheads on sago pondweed. Master's thesis. Brookings: South Dakota State University (see Supplemental Material, Reference S3, http://dx.doi.org/10.3996/ 082012-JFWM-072.S3); also available: http://pubstorage. sdstate.edu/wfs/thesis/Kolterman-Bret-F-M-S-1990.pdf (November 2012).

Lind OT. 1985. Handbook of common methods in limnology. Dubuque, lowa: Kendall Hunt.

Lott JP. 1991. Food habits of yellow perch in eastern South Dakota glacial lakes. Master's thesis. Brookings: South Dakota State University (see Supplemental Material, Reference S4, http://dx.doi.org/10.3996/082012-JFWM072.S4); also available: http://pubstorage.sdstate.edu/ wfs/thesis/Lott-John-P-MS-1991.pdf (November 2012).

Lott JP, Willis DW, Lucchesi DO. 1996. Relationship of food habits to yellow perch growth and population structure in South Dakota lakes. Journal of Freshwater Ecology 11:27-37.

Lott JP, Willis DW, Lucchesi DO. 1998. Zooplankton structural indices as indicators of yellow perch population characteristics. Prairie Naturalist 30:111122.

Lynch M, Weider LJ, Lampert W. 1986. Measurement of the carbon balance in Daphnia. Limnology and Oceanography 31:17-33.

Mallory ML, Blancher PJ, Weatherhead PJ, McNicol DK. 1994. Presence or absence of fish as a cue to macroinvertebrate abundance in boreal wetlands. Hydrobiologia 279-280:345-351.

Mason CF. 1977. Populations and production of benthic animals in two contrasting shallow lakes in Norfolk. Journal of Animal Ecology 46:147-172.
McCarraher DB. 1960. The Nebraska Sandhill lakes: their characteristics and fisheries management problems. Nebraska Game and Parks Commission, White Papers, Conference Presentations, and Manuscripts, Paper 7 (see Supplemental Material, Reference S5, http://dx.doi.org/ 10.3996/082012-JFWM-072.S5); also available: http:// digitalcommons.unl.edu/cgi/viewcontent.cgi?article $=1006 \&$ context $=$ nebgamewhitepap (March 2013).

McCarraher DB, Gregory RW. 1970. Adaptability and current status of introductions of Sacramento perch, Archoplites interruptus, in North American. Transactions of the American Fisheries Society 99:700-707.

McCarraher DB, Thomas R. 1968. Some ecological observations on the fathead minnow, Pimephales promelas, in the alkaline waters of Nebraska. Transactions of the American Fisheries Society 97:52-55.

McCauley E, Kalff J. 1981. Empirical relationships between phytoplankton and zooplankton biomass in lakes. Canadian Journal of Fisheries and Aquatic Sciences 38: 458-463.

McEwen DC, Butler MG. 2010. The effects of water-level manipulation on the benthic invertebrates of a managed reservoir. Freshwater Biology 55:1086-1101.

Mills EL, Green DM, Schiavone A Jr. 1987. Use of zooplankton size to assess the community structure of fish populations in freshwater lakes. North American Journal of Fisheries Management 7:369-378.

Mills EL, Schiavone A Jr. 1982. Evaluation of fish communities through assessment of zooplankton populations and measures of lake productivity. North American Journal of Fisheries Management 2:14-27.

Northcote TG. 1988. Fish in the structure and function of freshwater ecosystems: a "top-down" view. Canadian Journal of Fisheries and Aquatic Sciences 45:361-379.

Pace ML. 1986. An empirical analysis of zooplankton community size structure across lake trophic gradients. Limnology and Oceanography 31:45-55.

Parkos JJ 3rd, Santucci VJ, Wahl DH. 2003. Effects of adult common carp (Cyprinus carpio) on multiple trophic levels in shallow mesocosms. Canadian Journal of Fisheries and Aquatic Sciences 60:182-192.

Paukert CP, Willis DW. 2003a. Aquatic invertebrate assemblages in shallow prairie lakes: fish and environmental influences. Journal of Freshwater Ecology 18:523-536.

Paukert CP, Willis DW. 2003b. Population characteristics and ecological role of northern pike in shallow natural lakes in Nebraska. North American Journal of Fisheries Management 23:313-322.

Paukert CP, Willis DW, Gabelhouse DW Jr. 2002. Effect and acceptance of bluegill length limits in Nebraska natural lakes. North American Journal of Fisheries Management 22:1306-1313.

Post DM, Carpenter SR, Christensen DL, Cottingham KL, Kitchell JF, Schindler DE. 1997. Seasonal effects of variable recruitment of a dominant piscivore on pelagic food web structure. Limnology and Oceanography 42:722-729. 
Prout MW, Mills EL, Forney JL. 1990. Diet, growth, and potential competitive interactions between age- 0 white perch and yellow perch in Oneida Lake, New York. Transactions of the American Fisheries Society 119:966-975.

Rabeni CF. 1996. Invertebrates. Pages 335-351 in Murphy BR, Willis DW, editors. Fisheries techniques. 2nd edition. Bethesda, Maryland: American Fisheries Society.

Rosenberg DM, Resh VH. 1996. Biomonitoring. Pages 8797 in Merritt RW, Cummins KW, editors. An introduction to the aquatic insects of North America. 3rd edition. Dubuque, lowa: Kendall Hunt.

Rundquist DC, Lawson MP, Queen LP, Cerveny RS. 1987. The relationship between summer-season rainfall events and lake-surface area. Water Resources Bulletin 23:493-508.

Ruxton GD, Beauchamp G. 2008. Time for some a priori thinking about post hoc testing. Behavioral Ecology 19:690-693.

SAS Institute. 2002. SAS/STAT user's guide, version 9.1. SAS Institute, Cary, North Carolina.

Scheffer M. 1990. Multiplicity of stable states in freshwater systems. Hydrobiologia 200-201:475-486.

Scheffer M. 1998. The ecology of shallow lakes. London: Chapman and Hall.

Scheffer M, Carpenter S, Foley JA, Folkes C, Walker B. 2001. Catastrophic shifts in ecosystems. Nature 413: 591-596.

Scheffer M, Hosper SH, Meijer M-L, Moss B, Jeppesen E. 1993. Alternative equilibria in shallow lakes. Trends in Ecology and Evolution 8:275-279.

Spencer CN, King DL. 1984. Role of fish in regulation of plant and animal communities in eutrophic ponds. Canadian Journal of Fisheries and Aquatic Sciences 41: 1851-1855.

Stevens JP. 2002. Applied multivariate statistics for the social sciences. 4th edition. Mahwah, New Jersey: Lawrence Erlbaum Associates.

Stewart T, Downing J. 2008. Macroinvertebrate communities and environmental conditions in recently constructed wetlands. Wetlands 28:141-150.

Swanson GA, Nelson HK. 1970. Potential influence of fish rearing programs on waterfowl breeding habitat. Pages 65-71 in Schneberger E, editor. A symposium on the management of midwestern winterkill lakes. North-Central Division, American Fisheries Society, Special Publication, Bethesda, Maryland.

[USFWS] U.S. Fish and Wildlife Service. 1999. Comprehensive conservation plan: Valentine National Wildlife Refuge. U.S. Department of the Interior, Fish and Wildlife Service, Denver, Colorado. Available: http://digitalmedia. fws.gov/cdm/singleitem/collection/document/id/581/rec/ 13 (January 2013).
Vadeboncoeur Y, Vander Zanden MJ, Lodge DM. 2002. Putting the lake back together: reintegrating benthic pathways into lake food web models. Bioscience 52: 44-54.

Van de Meutter F, Stoks R, De Meester L. 2005. The effect of turbidity state and microhabitat on macroinvertebrate assemblages: a pilot study of six shallow lakes. Hydrobiologia 542:379-390.

Wanner GA. 2007. 2007 fishery assessment surveys conducted on the Valentine National Wildlife Refuge. 2007 Annual Report, USFWS, Pierre, South Dakota. (see Supplemental Material, Reference S6, http://dx.doi.org/ 10.3996/082012-JFWM-072.S6); also available: http:// www.fws.gov/greatplainsfishandwildlife/documents/ 2007ValentineNWRFisheryReport.pdf (November 2012).

Wantzen K, Rothhaupt K-O, Mörtl M, Cantonati M, Tóth L, Fischer P. 2008. Ecological effects of water-level fluctuations in lakes: an urgent issue. Pages 1-4 in Wantzen K, Rothhaupt K-O, Mörtl M, Cantonati M, Tóth $L$, Fischer $P$, editors. Ecological effects of waterlevel fluctuations in lakes. Amsterdam: Springer.

Ward MC, Willis DW, Herwig BR, Chipps SR, Parsons BG, Reed JR, Hanson MA. 2008. Consumption estimates of walleye stocked as fry to suppress fathead minnow populations in west-central Minnesota wetlands. Ecology of Freshwater Fish 17:59-70.

Welker MT, Pierce CL, Wahl DH. 1994. Growth and survival of larval fishes: roles of competition and zooplankton abundance. Transactions of the American Fisheries Society 123:703-717.

Werner EE, Wellborn GA, McPeek MA. 1995. Diet composition in postmetamorphic bullfrogs and green frogs: implications for interspecific predation and competition. Journal of Herpetology 29:600-607.

Westfall PH, Tobias RD, Rom D, Wolfinger RD, Hochberg Y. 1999. Multiple comparisons and multiple tests using the SAS system. Cary, North Carolina: SAS Institute.

Wetzel RG, Likens GE. 1991. Limnological analyses. 2nd edition. New York: Springer-Verlag.

Whiteside MC, Swindoll CM, Doolittle WL. 1985. Factors affecting the early life history of yellow perch, Perca flavescens. Environmental Biology of Fishes 12:47-56.

Zimmer KD, Hanson MA, Butler MG. 2001. Effects of fathead minnow colonization and removal on a prairie wetland ecosystem. Ecosystems 4:346-357.

Zimmer KD, Hanson MA, Butler MG. 2003. Relationships among nutrients, phytoplankton, macrophytes, and fish in prairie wetlands. Canadian Journal of Fisheries and Aquatic Sciences 60:721-730.

Zimmer K, Hanson M, Herwig B, Konsti M. 2009. Thresholds and stability of alternative regimes in shallow prairie-parkland lakes of Central North America. Ecosystems 12:843-852. 